\title{
PENGARUH FAKTOR INDIVIDUAL DAN FAKTOR KONTEKSTUAL TERHADAP KEPUTUSAN UNTUK BEKERJA MIGRAN MUDA ANTARPROVINSI DI INDONESIA
}

\author{
Zulfikar Halim Lumintang
}

Badan Pusat Statistik, Kolaka, Indonesia

zulfikarhalimlumintang@gmail.com

\begin{abstract}
The Influence of Individual Factors and Contextual Factors on the Decision to Work of Young Migrants Between Provinces in Indonesia. Inter-provincial young migrants in Indonesia who have a working status reach $49.29 \%$. This means that nearly half of the total inter-provincial young migrants who enter the workforce. This number is relatively high, and will become a problem when these young migrants drop out of school to work for various reasons. It aims to determine the influence and tendency of individual factors and contextual factors in decision making to work for inter-provincial young migrants in Indonesia. With multilevel binary logistic regression, individual and contextual factors that significantly influence young migrant work decisions include gender, household status, school status, reasons for moving, and education level, dependency ratio and percentage of formal workers. There is a greater tendency to work for young male migrants, have status as the head of the household, are not in school anymore, the reason for moving is related to work, and their last education is higher education. Then, the tendency to work increases with the increase in dependency ratio and the percentage of formal workers in each province.
\end{abstract}

Keywords: Young Migrants; Working; Multilevel.

\begin{abstract}
Abstrak: Pengaruh Faktor Individual dan Faktor Kontekstual Terhadap Keputusan Untuk Bekerja Migran Muda Antarprovinsi di Indonesia. Migran muda antarprovinsi di Indonesia yang berstatus bekerja mencapai 49,29\%. Artinya, hampir setengah dari total migran muda antarprovinsi yang memasuki lapangan kerja. Jumlah tersebut tergolong tinggi, dan akan menjadi permasalahan ketika migran muda tersebut putus sekolah untuk bekerja dengan berbagai alasan. Bertujuan untuk mengetahui pengaruh dan kecenderungan faktor individual dan faktor kontekstual dalam pengambilan keputusan untuk bekerja migran muda antar provinsi di Indonesia. Dengan regresi logistik biner multilevel, faktor individual dan kontekstual yang signifikan memengaruhi keputusan bekerja migran muda diantaranya jenis kelamin, status dalam rumah tangga, status sekolah, alasan pindah, dan tingkat pendidikan, rasio ketergantungan dan persentase pekerja formal. Kecenderungan untuk bekerja lebih besar pada migran muda berjenis kelamin laki-laki, berstatus sebagai kepala rumah tangga, berstatus tidak bersekolah lagi, alasan pindahnya terkait pekerjaan, dan pendidikan terakhirnya adalah pendidikan tinggi. Kemudian, kecenderungan untuk bekerja semakin tinggi seiring dengan meningkatnya rasio ketergantungan dan persentase pekerja formal di tiap provinsi.
\end{abstract}

Kata kunci: Migran Muda; Bekerja; Multilevel. 


\section{PENDAHULUAN}

Migran muda antarprovinsi di Indonesia yang berstatus bekerja mencapai 49,29\%. Hal ini menunjukkan bahwa hampir setengah dari total migran muda antarprovinsi yang memasuki lapangan kerja. Jumlah tersebut tergolong tinggi, dan akan menjadi permasalahan ketika migran muda tersebut putus sekolah untuk bekerja dengan berbagai alasan. Temuan ini didukung oleh Pada tahun 2012 United Children's Work menyatakan bahwa pemuda harus mendapatkan bekal keterampilan hidup mendasar yang cukup, sebagai pembelajaran kehidupan di masa yang akan datang. Salah satu caranya adalah dengan memastikan kaum muda berhasil dalam masa peralihan dari dunia pendidikan menuju dunia pekerjaan di pasar tenaga kerja. Setelah mendapatkan pekerjaan yang layak, diharapkan pemuda akan memiliki peningkatan insentif guna menginvestasikan pendidikan anak-anak dalam siklus kehidupan.

Dengan melihat Tabel 1. dan Tabel 2. permasalahan akan lebih jelas terlihat, dimana masih tingginya migran muda yang putus sekolah di usia muda dan masuk ke dalam dunia kerja.

Pengklasifikasian usia sekolah di Indonesia adalah sebagai berikut :
a. Usia 7-12 tahun : SD/MI
b. Usia 13-15 tahun : SMP/MTs
c. Usia 16-18 tahun : SMA/MA
d. Usia 19-24 tahun : PT

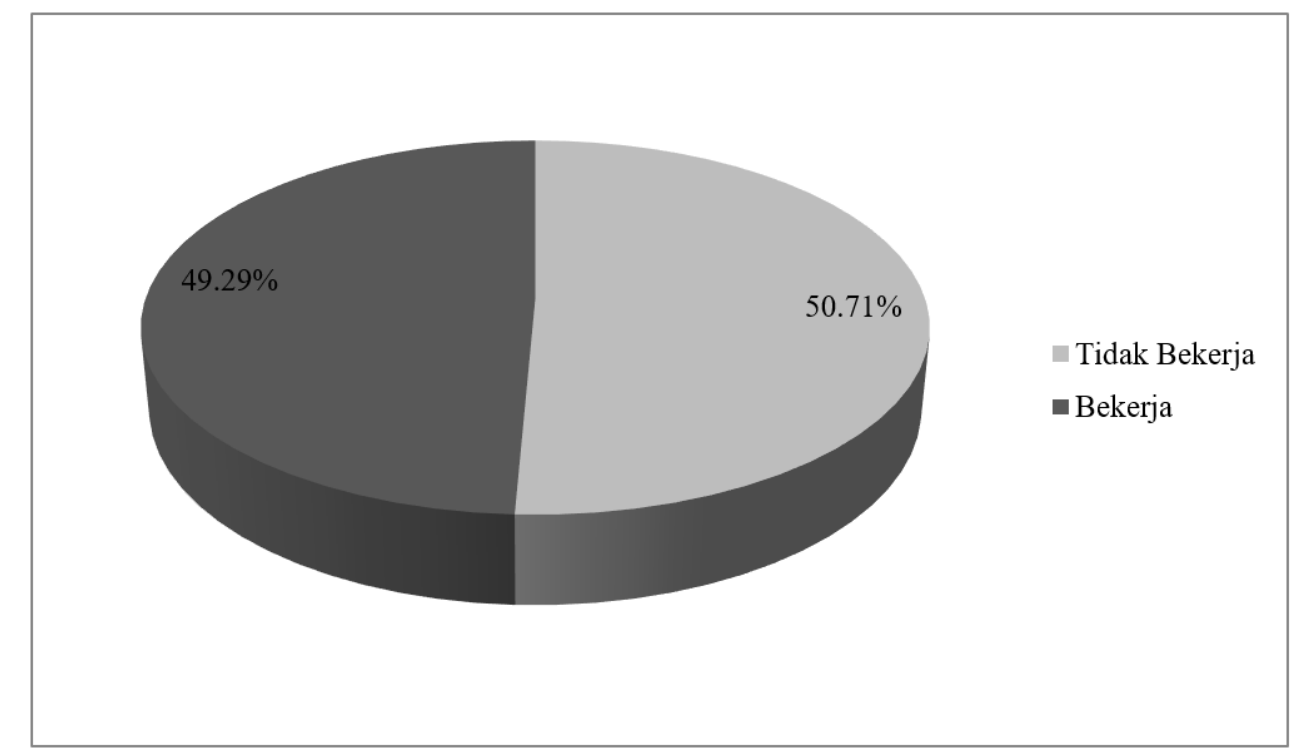

Sumber : SUPAS 2015 (diolah)

Gambar 1.

Keputusan migran muda antarprovinsi di Indonesia untuk bekerja tahun 2015 
Tabel 1.

Karakteristik Migran Muda Berdasarkan Usia, Status Sekolah dan Status Bekerja

\begin{tabular}{cccc}
\hline \hline \multirow{2}{*}{ Usia } & Status Sekolah & \multicolumn{2}{c}{ Status Bekerja } \\
\cline { 3 - 4 } & & Tidak Bekerja & Bekerja \\
\hline \multirow{2}{*}{$\mathbf{( 1 )}$} & $\mathbf{( 2 )}$ & $\mathbf{( 3 )}$ & $\mathbf{( 4 )}$ \\
\hline \multirow{1}{*}{$\mathbf{1 5}$} & Masih bersekolah & $69,0 \%$ & $3,6 \%$ \\
\cline { 2 - 4 } & Tidak bersekolah lagi & $10,0 \%$ & $17,3 \%$ \\
\hline \multirow{2}{*}{$\mathbf{1 6}$} & Masih bersekolah & $59,9 \%$ & $3,9 \%$ \\
\cline { 2 - 4 } & Tidak bersekolah lagi & $12,3 \%$ & $23,9 \%$ \\
\hline \multirow{2}{*}{$\mathbf{1 7}$} & Masih bersekolah & $43,0 \%$ & $2,4 \%$ \\
\cline { 2 - 4 } & Tidak bersekolah lagi & $20,5 \%$ & $34,1 \%$ \\
\hline & Masih bersekolah & $30,0 \%$ & $1,9 \%$ \\
\hline & Tidak bersekolah lagi & $27,0 \%$ & $41,1 \%$ \\
\hline
\end{tabular}

Sumber : SUPAS 2015 (diolah)

Berdasarkan Tabel 1 diperoleh hasil bahwa migran muda yang berusia 15 tahun yang tidak melanjutkan sekolah lagi dan memilih untuk bekerja adalah 17,3\%. Artinya, migran muda berusia 15 tahun tersebut maksimal masih lulusan SMP/MTs, namun sudah memasuki dunia kerja. Angka migran muda yang tidak melanjutkan sekolah lagi dan memilih bekerja semakin meningkat seiring dengan meningkatnya usia. Usia 16 tahun sebanyak 23,9\%, 17 tahun sebanyak 34,1\%, dan 18 tahun sebanyak $41,1 \%$.

Migran muda yang berusia 19-24 tahun harapannya dapat melanjutkan pendidikan ke Perguruan Tinggi untuk meningkatkan modal kemampuan dan keterampilannya agar memiliki bekal yang cukup dalam memasuki dunia kerja. Namun, pola pikir dan kemampuan ekonomi
Tabel 2. Migran Muda Usia 19-24 Tahun yang Pendidikan Tertingginya SMP/MTs dan Memilih Bekerja

\begin{tabular}{cc}
\hline Usia & $\begin{array}{c}\text { Putus Sekolah dan } \\
\text { Bekerja }\end{array}$ \\
\hline $\mathbf{( 1 )}$ & $\mathbf{( 2 )}$ \\
\hline $\mathbf{1 9}$ & $22,92 \%$ \\
\hline $\mathbf{2 0}$ & $21,77 \%$ \\
\hline $\mathbf{2 1}$ & $21,13 \%$ \\
\hline $\mathbf{2 2}$ & $21,12 \%$ \\
\hline $\mathbf{2 3}$ & $21,90 \%$ \\
\hline $\mathbf{2 4}$ & $21,67 \%$ \\
\hline
\end{tabular}

Sumber : SUPAS 2015 (diolah)

masyarakat yang terbatas membuat mereka lebih memilih untuk bekerja dengan bekal pendidikan maksimal SMA atau sederajat. Selain itu, berdasarkan Tabel 2. Migran muda usia 19-24 tahun yang paling tinggi berpendidikan SMP/ MTs tidak bersekolah lagi dan memilih untuk bekerja mencapai 21\%-22\%, angka tersebut tentu akan menambah pekerja berpendidikan 
rendah yang akan memiliki upah rendah di provinsi dengan persentase migran muda yang Indonesia dan hal tersebut akan menyebabkan bekerja mencapai lebih dari $60 \%$. Di lain pihak pekerja Indonesia mengalami kesulitan dalam provinsi D.I. Yogyakarta merupakan provinsi memasuki lapangan kerja ketika persaingan dengan persentase migran muda yang bekerja bebas tenaga kerja dilaksanakan. paling rendah yaitu mencapai $20,00 \%$.

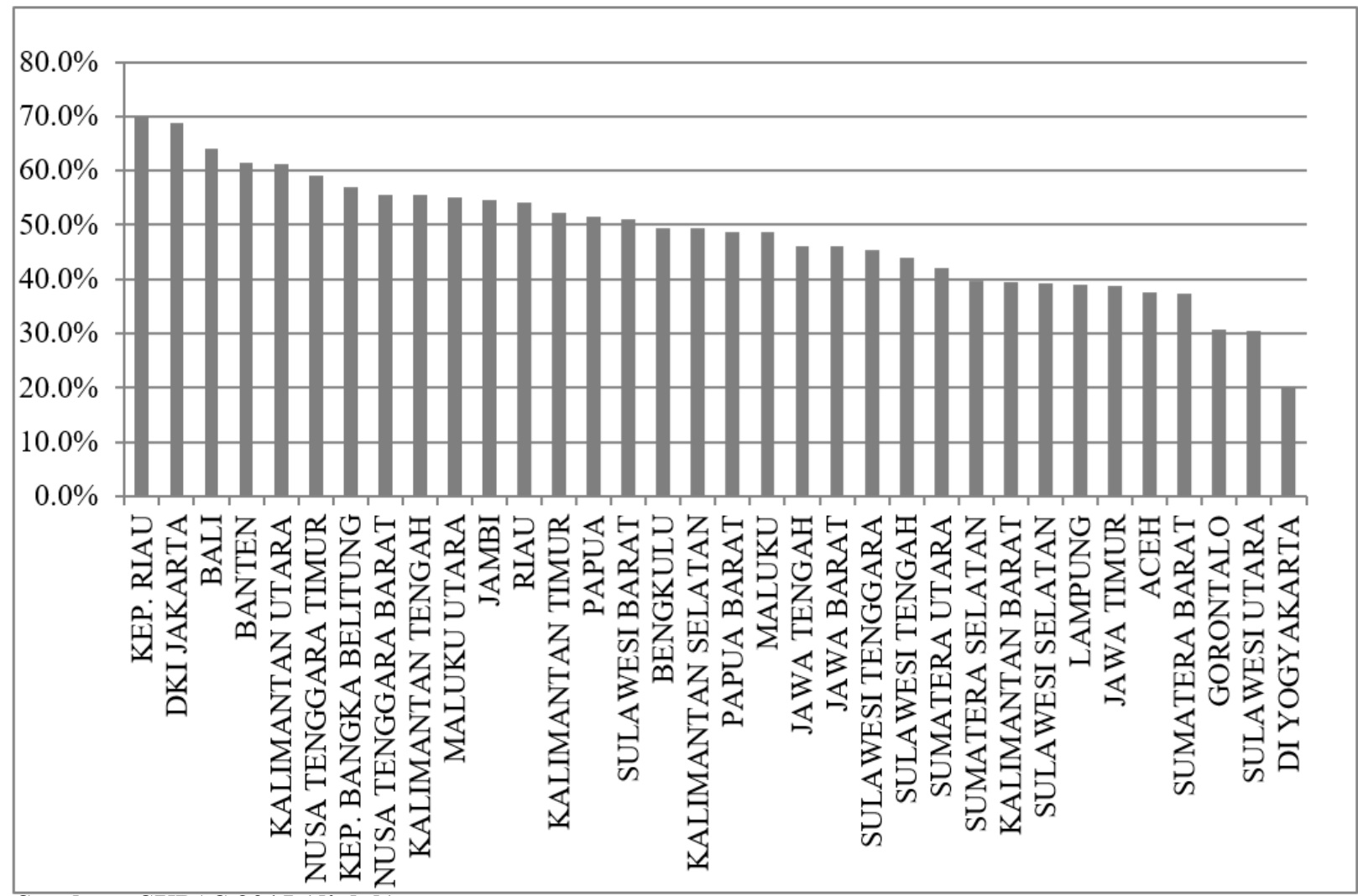

Sumber : SUPAS 2015 (diolah)

\section{Gambar 2. Persentase keputusan untuk bekerja migran muda antarprovinsi menurut provinsi tujuan migrasi di Indonesia tahun 2015}

Terdapat perbedaan keputusan untuk bekerja migran muda antarprovinsi di seluruh provinsi di Indonesia dengan variasi yang cukup tinggi. Rata-rata persentase secara nasional migran muda yang bekerja mencapai $49,3 \%$. Provinsi Kepulauan Riau, DKI Jakarta, Bali, umur yang lain, pemuda memiliki tingkat Banten, dan Kalimantan Utara merupakan migrasi internal tertinggi di Indonesia yaitu

Hal ini menunjukkan adanya peran perbedaan karakteristik antarprovinsi terhadap keputusan migran muda untuk bekerja di provinsi tujuan migrasi di Indonesia.

Jika dibandingkan dengan kelompok 
mencapai 33,48\% dan bukti-bukti menunjukkan arus utamanya adalah dari desa ke kota di mana pendidikan dan kesempatan kerja lebih besar. Pemuda dengan tingkat pendidikan yang lebih tinggi lebih cenderung untuk pindah ke wilayah lain daripada pemuda berpendidikan rendah. Oleh karena itu, pemuda merupakan aset penting bagi masa depan bangsa.

Pemuda cenderung memiliki lifetime returns lebih tinggi dan biaya yang lebih rendah dalam bermigrasi. Ditambah lagi, populasi usia kerja pada kawasan yang kurang maju akan mengalami pertumbuhan terhadap proporsi keseluruhan, dari 43\% pada tahun 2010 menjadi 46\% pada tahun 2050 (International Labour Organization, 2015). Berdasarkan Statistik Migrasi tahun 2010, migran muda risen antarprovinsi di Indonesia mencapai 33,49\%. Migran risen itu sendiri merupakan penduduk yang pernah pindah dalam kurun 5 tahun terakhir (mulai dari 5 tahun sebelum pencacahan). Pemuda migran risen antarprovinsi tersebut, 70,94\% masuk ke dalam kategori Economically Active dimana pemuda sudah berstatus bekerja, mencari pekerjaan, maupun bersedia bekerja ketika ada tawaran pekerjaan. Dan sisanya, $29,06 \%$ masuk dalam kategori Not Economically
Active atau bukan angkatan kerja.

Migrasi memiliki efek yang kuat pada redistribusi modal manusia di provinsi-provinsi (Coulombe, 2006). Melalui proses migrasi antarprovinsi, modal manusia didistribusikan dari pedesaan menuju perkotaan dan dari provinsi yang miskin menuju provinsi yang kaya. Pada tahun 2010, lima provinsi dengan persentase migran muda tertinggi adalah Provinsi, D.I. Yogyakarta 60,55\%, Kepulauan Riau 48,26\%, DKI Jakarta 48,16\%, Bali 35,92\%, dan Papua Barat 30,16\%. Kemudian 74,9\% migran muda di provinsi Kepulauan Riau bermigrasi dengan alasan ingin mencari maupun mutasi pekerjaan. Sedangkan di provinsi D.I. Yogyakarta $86,4 \%$ migran mudanya beralasan bukan karena mencari maupun mutasi pekerjaan. Hal tersebut menunjukkan perbedaan karakteristik wilayah yang menjadi tujuan migran muda juga menunjukkan perbedaan alasan dalam bermigrasi.

Migrasi dapat menjadi pengalaman yang positif bagi pemuda (15-24 tahun) dan dapat memberikan kehidupan yang lebih baik, meningkatkan peluang dan melarikan diri dari ancaman langsung seperti kawin paksa, konflik dan bencana alam, namun migran muda dapat 
menghadapi tantangan serius saat bermigrasi. rumah tangga, status sekolah, alasan pindah, Tantangan-tantangan ini sangat serius ketika dan pendidikan terakhir. Faktor kontekstual anak bermigrasi tanpa dokumen dan/atau tanpa terdiri dari peluang untuk bekerja adalah keluarga, di mana perlindungan hukum masih rasio ketergantungan wilayah, upah minimum kurang diperhatikan dan di mana anak-anak regional dan persentase pekerja sektor formal dicegah dari mengakses layanan dasar seperti wilayah.

pendidikan dan kesehatan. Dalam situasi ini, Penelitian ini mencoba untuk pemuda migran berada pada risiko tinggi untuk mengidentifikasi pengaruh faktor individual dieksploitasi dan rentan terhadap pekerja anak. dan kontekstual dalam pengambilan keputusan Banyak migran muda berakhir di pertanian untuk bekerja migran muda antarprovinsi di atau layanan seperti pekerjaan rumah tangga. Indonesia. Selama ini, faktor individual dan Permasalahan akan semakin kompleks ketika faktor kontekstual diteliti secara terpisah untuk kebijakan Pasar Bebas Tenaga Kerja diterapkan dilihat pengaruhnya. Namun, dalam penelitian di Indonesia. Diperkirakan, persaingan dan ini faktor tersebut akan diteliti secara simultan mobilitas tenaga kerja akan terjadi secara bebas. dalam satu permodelan statistik, sehingga Tenaga kerja dari negara lain yang unggul dari bisa dilihat pengaruh dan kecenderungannya. segi pendidikan dan keterampilan akan dapat Berikut hipotesis pengaruh faktor individual bersaing dan masuk ke dalam pasar tenaga kerja dan faktor kontekstual terhadap status bekerja dibandingkan tenaga kerja yang kurang dari segi pendidikan dan keterampilan.

Pada penelitian ini, objek penelitian dibatasi pada migran kelompok umur muda (15-24 tahun), sesuai dengan rekomendasi ILO dan PBB, yang berstatus bekerja maupun tidak bekerja. Variabel yang diteliti meliputi faktor individual dan faktor kontekstual. Faktor individual terdiri dari jenis kelamin, status dalam migran muda antarprovinsi di Indonesia: $\mathrm{H1}$ : Variabel jenis kelamin diduga memengaruhi keputusan migran muda untuk bekerja. $\mathrm{H} 2$ : Variabel status dalam rumah tangga diduga memengaruhi keputusan migran muda untuk bekerja.

H3 : Variabel status sekolah diduga memengaruhi keputusan migran muda untuk bekerja. $\mathrm{H} 4$ : Variabel alasan pindah diduga memengaruhi 
keputusan migran muda untuk bekerja.

H5 : Variabel pendidikan terakhir diduga memengaruhi keputusan migran muda untuk bekerja.

H6 : Variabel rasio ketergantungan diduga memengaruhi keputusan migran muda untuk bekerja.

H7 : Variabel upah minimum regional diduga memengaruhi keputusan migran muda untuk bekerja.

H8 : Variabel persentase pekerja sektor formal wilayah diduga memengaruhi keputusan migran muda untuk bekerja.

\section{METODE PENELITIAN}

ILO menegaskan bahwa pada tahun 2015, Indonesia memiliki pekerja lepas sebanyak 11,9 juta jiwa. Angka tersebut merupakan tertinggi dalam periode 2011-2015. Lebih jauh lagi, menurut ILO pekerja lepas sangat identik dengan pekerja yang rentan terhadap upah yang rendah. Oleh karena itu, fenomena ekonomi ketenagakerjaan pada tahun 2015 harus diteliti lebih jauh, terutama terkait migran muda. Data yang digunakan dalam penelitian ini adalah data sekunder dari Badan Pusat Statistik, antara lain data mentah Survei Penduduk Antar Sensus
(SUPAS) 2015, website Badan Pusat Statistik, dan publikasi Indikator Pasar Tenaga Kerja Indonesia Agustus 2015.

Penelitian ini menggunakan dua metode analisis, analisis deskriptif dan analisis inferensia. Analisis deskriptif merupakan teknik analisis statistik dengan menyajikan data dalam bentuk tabel, grafik, scatterplot dan gambar. Analisis inferensia yang digunakan dalam penelitian ini adalah analisis regresi logistik biner multilevel untuk menganalisis pengaruh faktor individual dan faktor kontekstual status bekerja migran muda di 34 provinsi di Indonesia. Data yang digunakan dalam penelitian ini diolah menggunakan Microsoft Excel 2010 dan STATA 13.

Pemodelan multilevel digunakan karena data yang dimiliki berkerumun dan berhierarki. Pemodelan multilevel juga memiliki kelebihan diantaranya tidak hanya mengelompokkan individu ke dalam kelompok tertentu, tetapi juga memiliki variabel yang diukur pada setiap tingkatan. (Hox, 2002).

Goldstein (1998) memberikan penjelasan bahwa hampir semua jenis data sosial memiliki struktur hirarki atau berkerumun. Adanya hirarki data tersebut tidak disengaja 
Tabel 3. Penjelasan Variabel Penelitian

\begin{tabular}{|c|c|c|}
\hline Variabel & Notasi & Penjelasan \\
\hline (1) & (2) & (3) \\
\hline \multicolumn{3}{|c|}{ Variabel Dependen } \\
\hline Status Bekerja & status_kerja & $\begin{array}{l}0=\text { Tidak bekerja } \\
1=\text { Bekerja }\end{array}$ \\
\hline \multicolumn{3}{|c|}{ Variabel Independen } \\
\hline \multicolumn{3}{|c|}{ Faktor Individual } \\
\hline Jenis Kelamin & jenis_kelamin & $\begin{array}{l}0=\text { Perempuan } \\
1=\text { Laki-laki }\end{array}$ \\
\hline $\begin{array}{c}\text { Status dalam Rumah } \\
\text { Tangga }\end{array}$ & status_dalam_ruta & $\begin{array}{l}0=\text { Bukan KRT } \\
1=\text { KRT }\end{array}$ \\
\hline Status Sekolah & status_sekolah & $\begin{array}{l}0=\text { Masih Bersekolah } \\
1=\text { Tidak Bersekolah } \\
\text { Lagi }\end{array}$ \\
\hline Alasan Pindah & alasan_pindah & $\begin{array}{l}0=\text { Tidak terkait } \\
\text { pekerjaan } \\
1=\text { Terkait pekerjaan }\end{array}$ \\
\hline Pendidikan Terakhir & Pendidikan & $\begin{array}{l}0=\text { Dasar } \\
1=\text { Menengah } \\
2=\text { Tinggi }\end{array}$ \\
\hline \multicolumn{3}{|c|}{ Faktor Kontekstual } \\
\hline Rasio Ketergantungan & rasio_ketergantungan & Numerik \\
\hline $\begin{array}{c}\text { Upah Minimum } \\
\text { Regional }\end{array}$ & upah_minimum_regional & Numerik \\
\hline $\begin{array}{l}\text { Persentase Pekerja } \\
\text { Sektor Formal }\end{array}$ & persentase_pekerja_formal & Numerik \\
\hline
\end{tabular}

atau tidak dapat diketahui. Ini tercermin dalam semua jenis kegiatan sosial dimana perbedaan di antara lembaga-lembaga merupakan akibat dari perbedaan karakteristik orang-orang di dalam masing-masing lembaga tersebut.

Terdapat dua model dalam penelitian multilevel, yaitu null model dan conditional model. Null model atau yang disebut dengan intercept-only model merupakan model logistik biner.

tanpa variabel independen. Fungsi dari null model adalah untuk mengestimasi intraclass correlation dan memberikan patokan nilai deviance yang mengukur derajat ketetapan model yang digunakan. Sedangkan conditional model merupakan model yang terdapat variabel independen di dalamnya, baik variabel independen pada level 1 maupun level 2. Di dalam penelitian ini, Conditional model dengan dua level tersebut merupakan model multilevel

Terdapat kesamaan dalam interpretasi model regresi logistik satu level dan model 
multilevel regresi logistik, namun dalam multilevel regresi logistik terdapat parameter tambahan yang diestimasi, yaitu efek random. Efek random menunjukkan efek dari variasi antarkelompok pada level 2. Efek random dalam pemodelan multilevel terdiri atas dua bentuk, yaitu random intercept dan random slope. Berikut rincian dari kedua bentuk pemodelan dalam multilevel :

Model multilevel dengan random intercept. Merupakan model yang mengasumsikan bahwa setiap kelompok memiliki intercept yang berbeda-beda, tidak seperti intercept yang terdapat pada regresi biasa, namun slope dalam model ini sama sehingga pengaruh setiap variabel independen terhadap variabel dependen sama untuk setiap kelompok.

Model multilevel dengan random slope. Merupakan model yang mengasumsikan bahwa setiap kelompok memiliki slope yang berbeda-beda, tidak seperti slope yang terdapat dalam regresi biasa sehingga pengaruh setiap variabel independen berbeda-beda untuk setiap kelompok.

Untuk mencapai tujuan yang ingin dicapai dalam penelitian ini, yaitu mengetahui pengaruh variasi antarunit level 2 (provinsi) terhadap keputusan untuk bekerja migran muda dengan mengasumsikan pengaruh setiap variabel penjelas untuk tiap kelompok (provinsi) adalah sama. Maka digunakan model multilevel dengan random intercept.

Berikut model regresi logistik multilevel biner dengan random intercept untuk mengetahui keputusan bekerja migran muda antarprovinsi di Indonesia dalam penelitian ini (Hox, 2002) :

Level 1 (Individu)

$$
\begin{aligned}
& \ln \left(\frac{\pi_{i j}}{1-\pi_{i j}}\right)=\beta_{0 j}+\beta_{1 j} \text { jenis }_{\text {kelamin }_{i j}}+ \\
& \beta_{2 j} \text { status }_{\text {dalam }_{\text {ruta }}}+\beta_{3 j} \text { status }_{\text {sekolah }_{i j}}+ \\
& \beta_{4 j} \text { alasan }_{\text {pindah }_{i j}}+\beta_{51 j} \text { pendidikan }_{\text {menengah }} \text { pij } \\
& +\beta_{52 \mathrm{j}} \text { pendidikan_tinggi } i_{\mathrm{ij}}+\varepsilon_{\mathrm{ij}}
\end{aligned}
$$

Level 2 (Provinsi)

$$
\begin{aligned}
& \beta_{0 \mathrm{j}}=\gamma_{00}+\gamma_{01} \text { rasio }_{\text {ketergantungan }_{j}} \\
& +\gamma_{02} \text { upah }_{\text {minimum }} \text { regional }_{j} \\
& +\gamma_{03} \text { persentase_pekerja_formal }_{j}+u_{0 j} \\
& \beta_{1 \mathrm{i}}=\gamma_{10} ; \beta_{2 \mathrm{i}}=\gamma_{20} \\
& \beta_{3 \mathrm{j}}=\gamma_{30} ; \beta_{4 \mathrm{j}}=\gamma_{40} \\
& \beta_{51 \mathrm{j}}=\gamma_{510} ; \beta_{52 \mathrm{j}}=\gamma_{520}
\end{aligned}
$$

Maka model gabungan atau model multilevel logistik biner (dua level) adalah :

$$
\begin{aligned}
& \ln \left(\frac{\pi_{\mathrm{ij}}}{1-\pi_{\mathrm{ij}}}\right)=\gamma_{00}+\gamma_{10} \text { jenis }_{\text {kelamin }_{\mathrm{ij}}}+ \\
& \gamma_{20} \text { status }_{\text {dalam }_{\text {ruta }_{\mathrm{ij}}}}+\gamma_{30} \text { status }_{\text {sekolah }_{\mathrm{ij}}} \\
& +\gamma_{40} \text { alasan }_{\text {pindah }_{\mathrm{ij}}}+\gamma_{510} \text { pendidikan }_{\text {menenga }_{\mathrm{ij}}} \\
& +\gamma_{520} \text { pendidikan }_{\text {tinggi }_{\mathrm{ij}}}+\gamma_{01} \text { rasio }_{\text {ketergantungan }_{\mathrm{j}}} \\
& +\gamma_{02} \text { upah }_{\text {minimum }_{\text {regional }}}+ \\
& \gamma_{03} \text { persentase_pekerja_formal }_{\mathrm{j}}+u_{0 j}+\varepsilon_{i j} \ldots . .
\end{aligned}
$$

i : individu (migran muda)

$\mathrm{j} \quad$ : provinsi

$\gamma_{00}$ : intercept (rata-rata keseluruhan) 
$\gamma_{\mathrm{p} 0} \quad$ : efek tetap untuk variabel penjelas ke- $p$ di level 1 (fixed slope)

$\gamma_{0 \mathrm{q}} \quad$ : efek tetap untuk variabel penjelas ke- $q$ di level 2

$\varepsilon_{\mathrm{ij}} \quad$ : residual untuk migran ke- $i$ di level 1 dalam provinsi ke-j

$\mathrm{u}_{\mathrm{ij}} \quad$ : random effect provinsi ke-j di level 2

\section{HASIL DAN PEMBAHASAN}

Hasil pengolahan data Survei Penduduk Antar Sensus tahun 2015 menunjukkan bahwa migran muda antarprovinsi di Indonesia didominasi oleh migran muda berjenis kelamin perempuan sebesar (53,66\%), berstatus bukan sebagai kepala rumah tangga $(84,36 \%)$, berstatus tidak bersekolah lagi $(75,04 \%)$, alasan pindahnya bukan karena mencari pekerjaan/pekerjaan $(56,50 \%)$, pendidikan terakhirnya tingkat menengah $(73,56 \%)$.
Gambar 3. menunjukkan bahwa persentase keputusan untuk bekerja migran muda antarprovinsi berjenis kelamin perempuan sebesar $37,20 \%$ dan migran muda antarprovinsi berjenis kelamin laki-laki yang memutuskan untuk bekerja sebesar $63,30 \%$.

Gambar 4. menunjukkan bahwa persentase keputusan untuk bekerja migran muda antarprovinsi yang berstatus sebagai bukan kepala rumah tangga sebesar $48,40 \%$ dan migran muda antarprovinsi yang berstatus sebagai kepala rumah tangga dengan status bekerja sebesar $54,00 \%$.

Gambar 5. menunjukkan bahwa persentase keputusan untuk bekerja migran

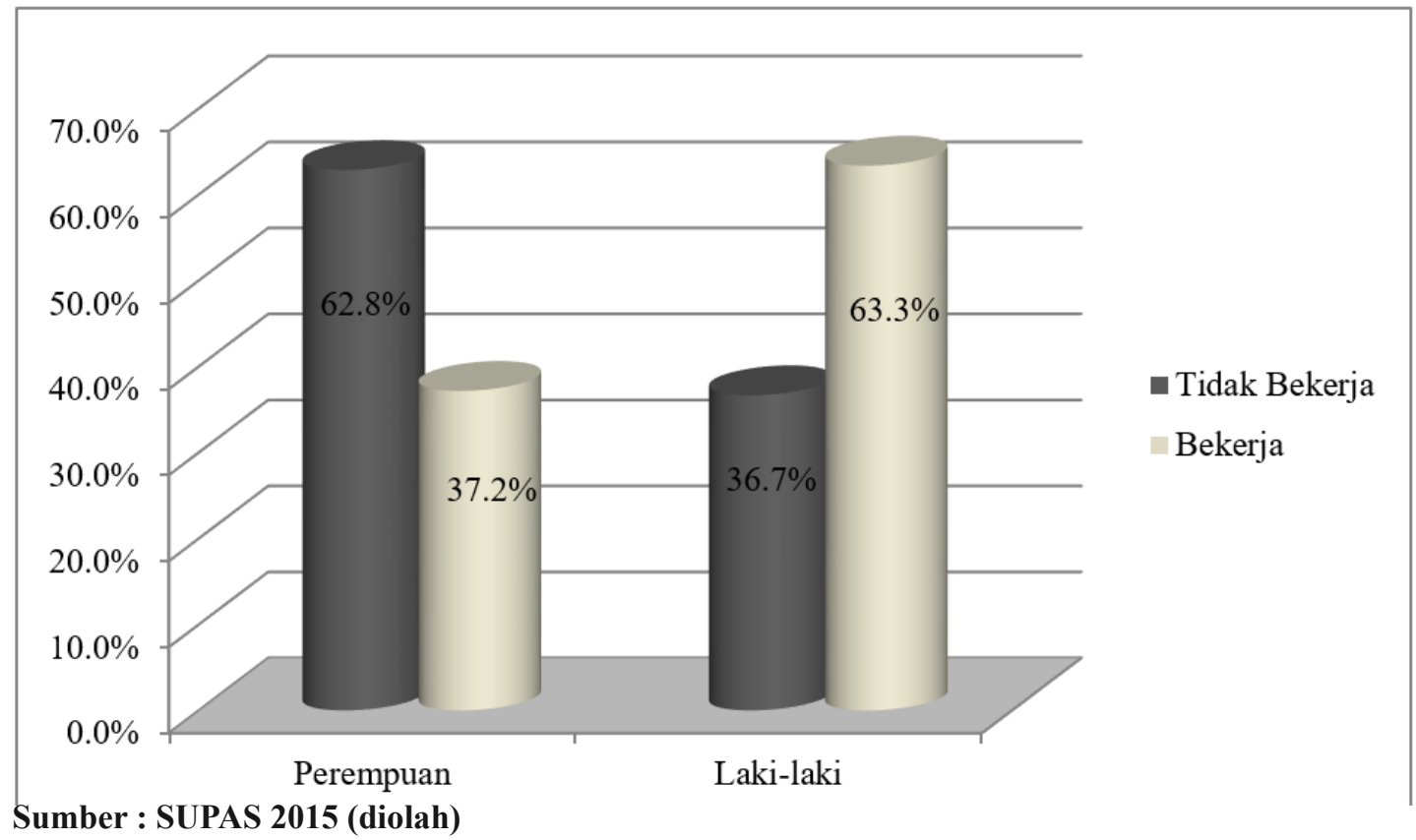

Gambar 3.

Persentase keputusan untuk bekerja migran muda antarprovinsi menurut jenis kelamin 


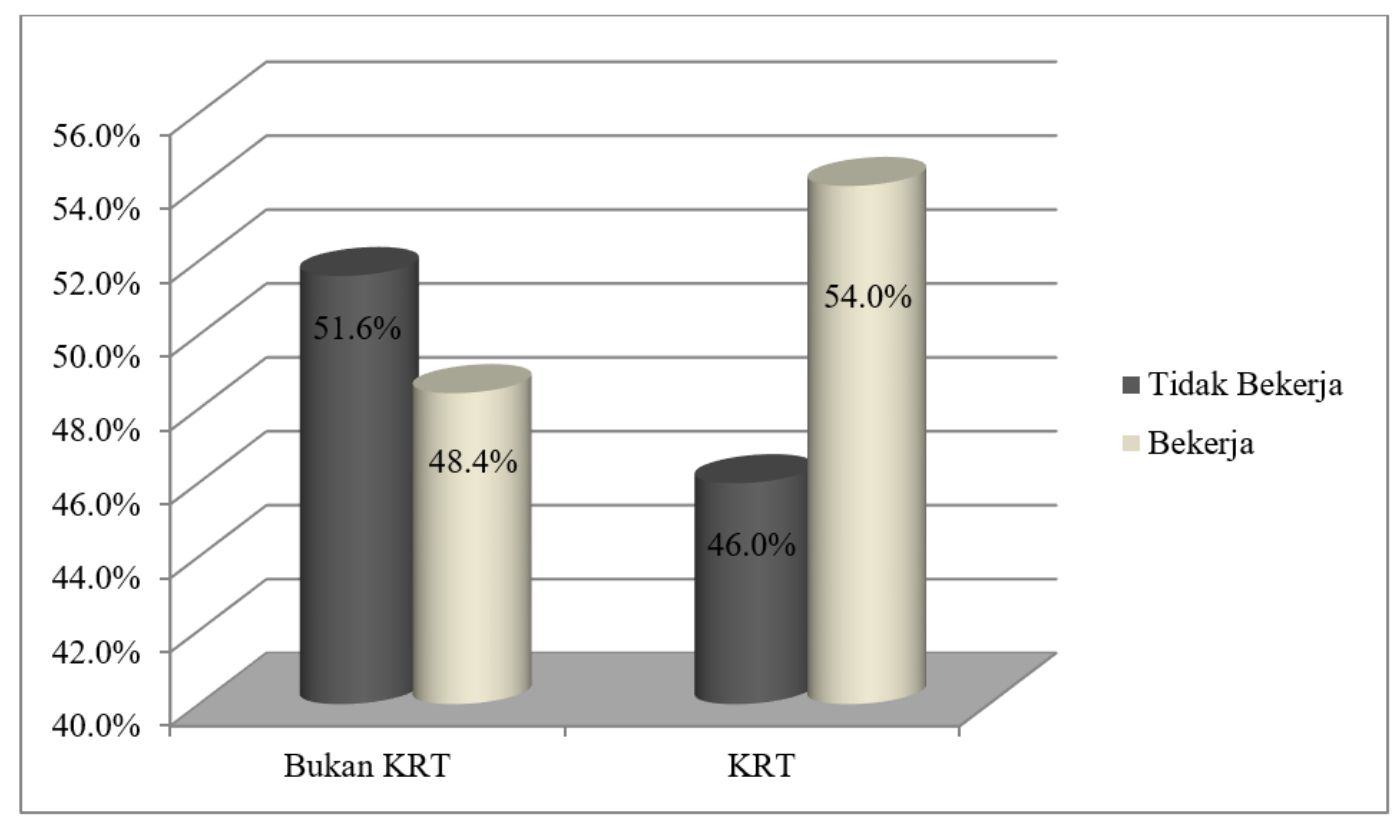

Sumber : SUPAS 2015 (diolah)

Gambar 4.

Persentase keputusan untuk bekerja migran muda antarprovinsi menurut status dalam rumah tangga

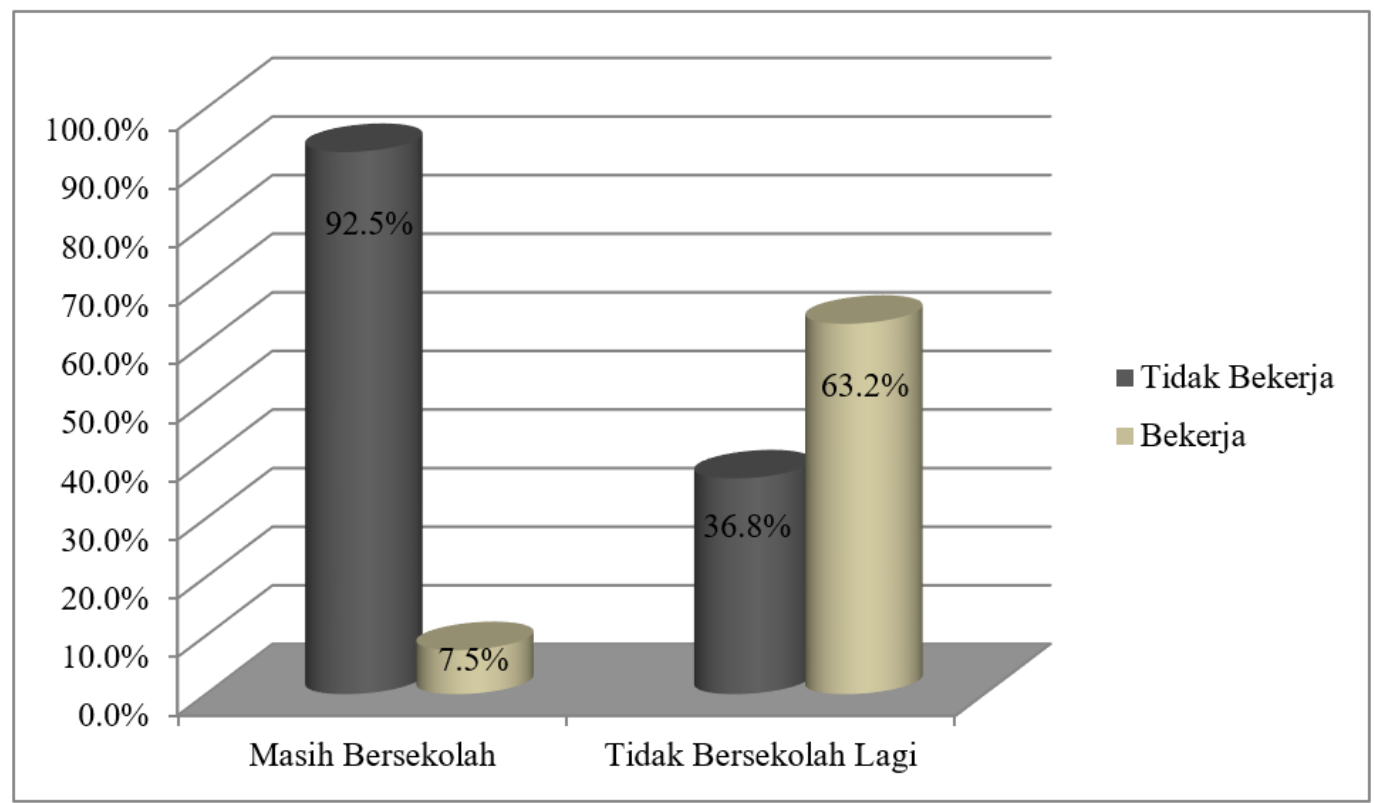

Sumber : SUPAS 2015 (diolah)

Gambar 5.

Persentase keputusan untuk bekerja migran muda antarprovinsi menurut status sekolah muda antarprovinsi yang berstatus masih antarprovinsi yang berstatus tidak bersekolah bersekolah sebesar 7,50\% dan migran muda lagi dengan status bekerja sebesar 63,20\%. 


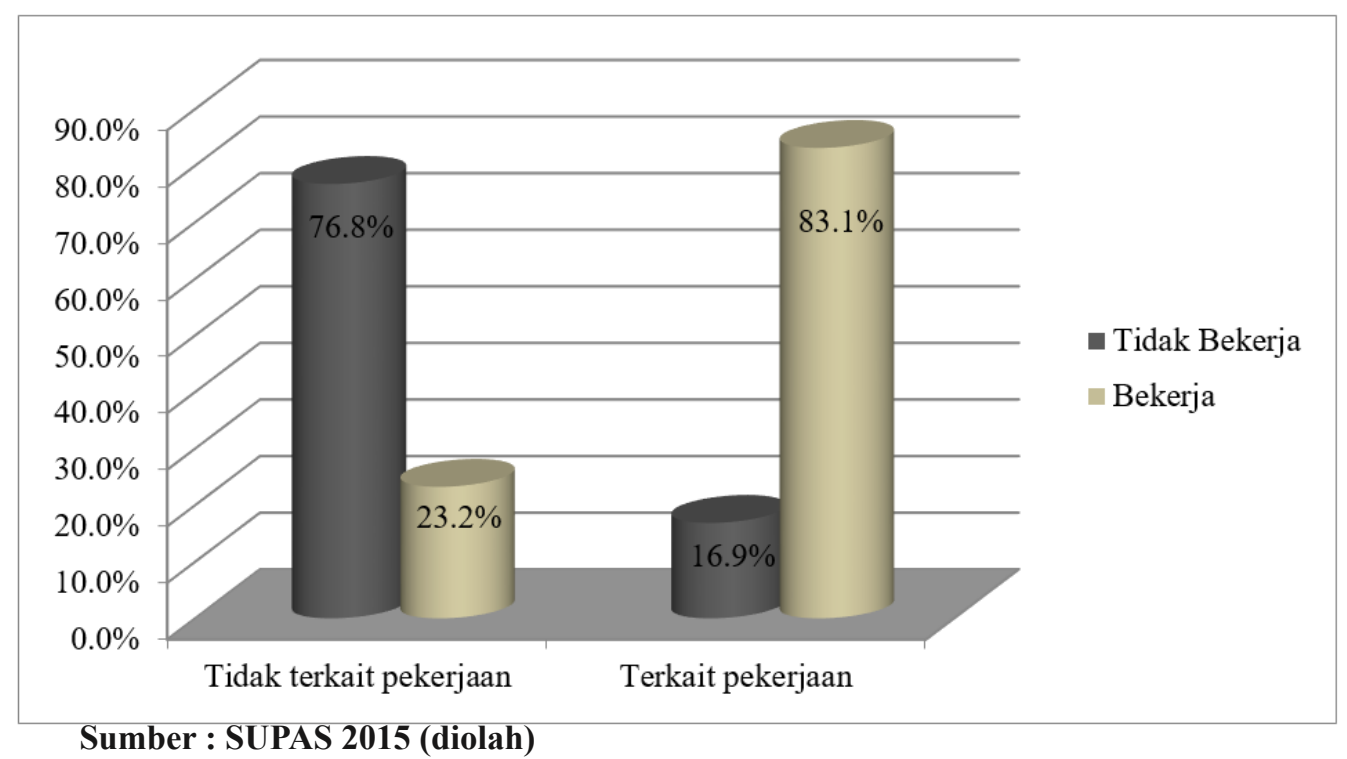

Gambar 6.

Persentase keputusan untuk bekerja migran muda antarprovinsi menurut alasan pindah

Gambar 6. menunjukkan bahwa Gambar 7. menunjukkan bahwa persentase keputusan untuk bekerja migran muda persentase keputusan untuk bekerja migran antarprovinsi yang alasan pindahnya tidak terkait muda antarprovinsi yang pendidikan terakhirnya pekerjaan sebesar 23,20\% dan migran muda pendidikan dasar 53,70\%, migran muda antarprovinsi yang alasan pindahnya terkait antarprovinsi yang pendidikan terakhirnya pekerjaan dengan status bekerja sebesar $83,10 \%$. pendidikan menengah dengan status bekerja

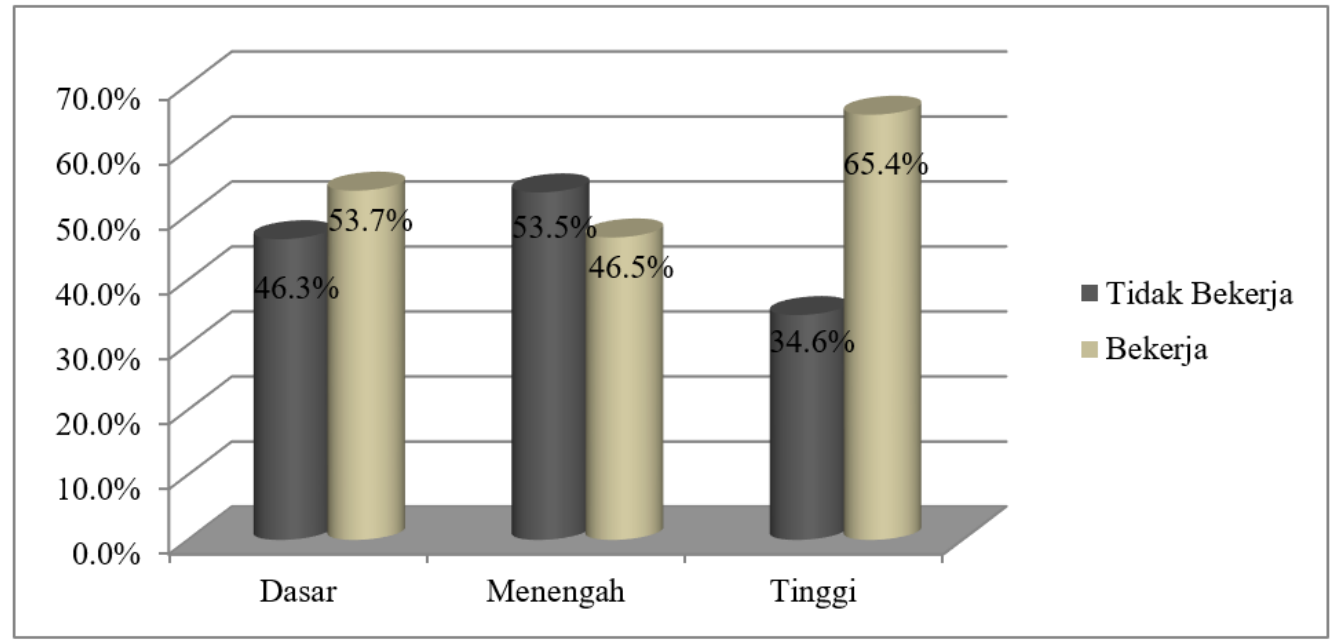

Sumber : SUPAS 2015 (diolah)

Gambar 7.

Persentase keputusan untuk bekerja migran muda antarprovinsi menurut pendidikan terakhir 


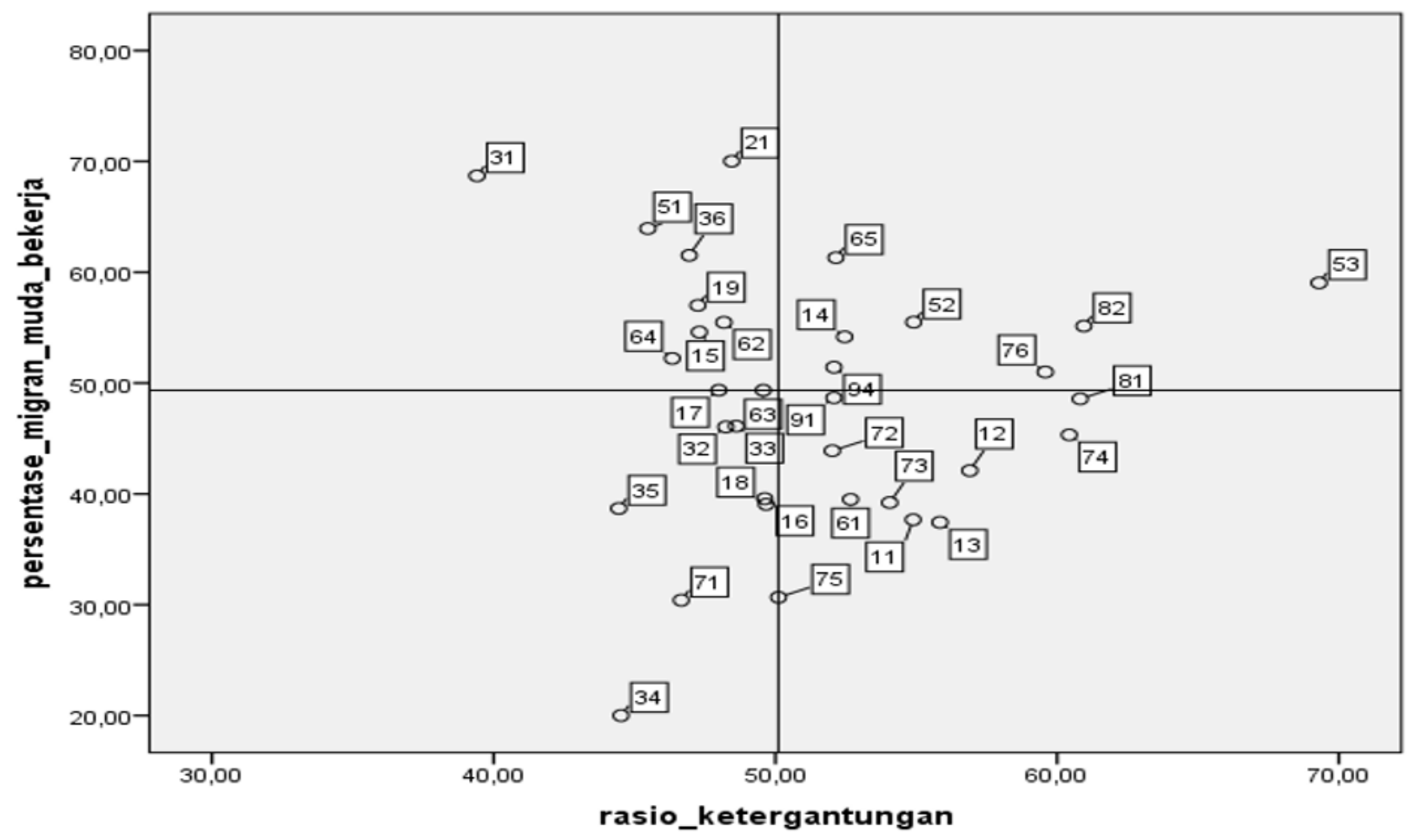

Sumber : Badan Pusat Statistik (diolah)

Gambar 8.

Scatterplot antara Persentase Migran Muda Bekerja dengan Rasio Ketergantungan

sebesar 46,50\%, migran muda antarprovinsi 67 penduduk usia belum produktif (0-14 tahun) yang pendidikan terakhirnya pendidikan tinggi dan tidak produktif lagi (65 tahun ke atas) di dengan status bekerja sebesar $65,40 \%$.

Nusa Tenggara Timur. Sedangkan provinsi DKI

Provinsi dengan kode 53 (Nusa Jakarta dengan kode 31 merupakan provinsi Tenggara Timur) merupakan provinsi dengan dengan persentase migran muda bekerja tinggi rasio ketergantungan tertinggi di Indonesia yaitu mencapai 68,70, namun memiliki rasio dengan persentase migran muda bekerjanya ketergantungan paling rendah di Indonesia. Hal sebesar 59,04. Artinya secara kasar dapat tersebut, secara kasar menggambarkan bahwa dikatakan bahwa lebih dari setengah migran lebih dari setengah migran muda di DKI Jakarta muda di Nusa Tenggara Timur berstatus masuk dalam pasar kerja dan ikut menanggung bekerja dan ikut serta dalam menanggung 66- 39-40 penduduk usia belum produktif (0-14 


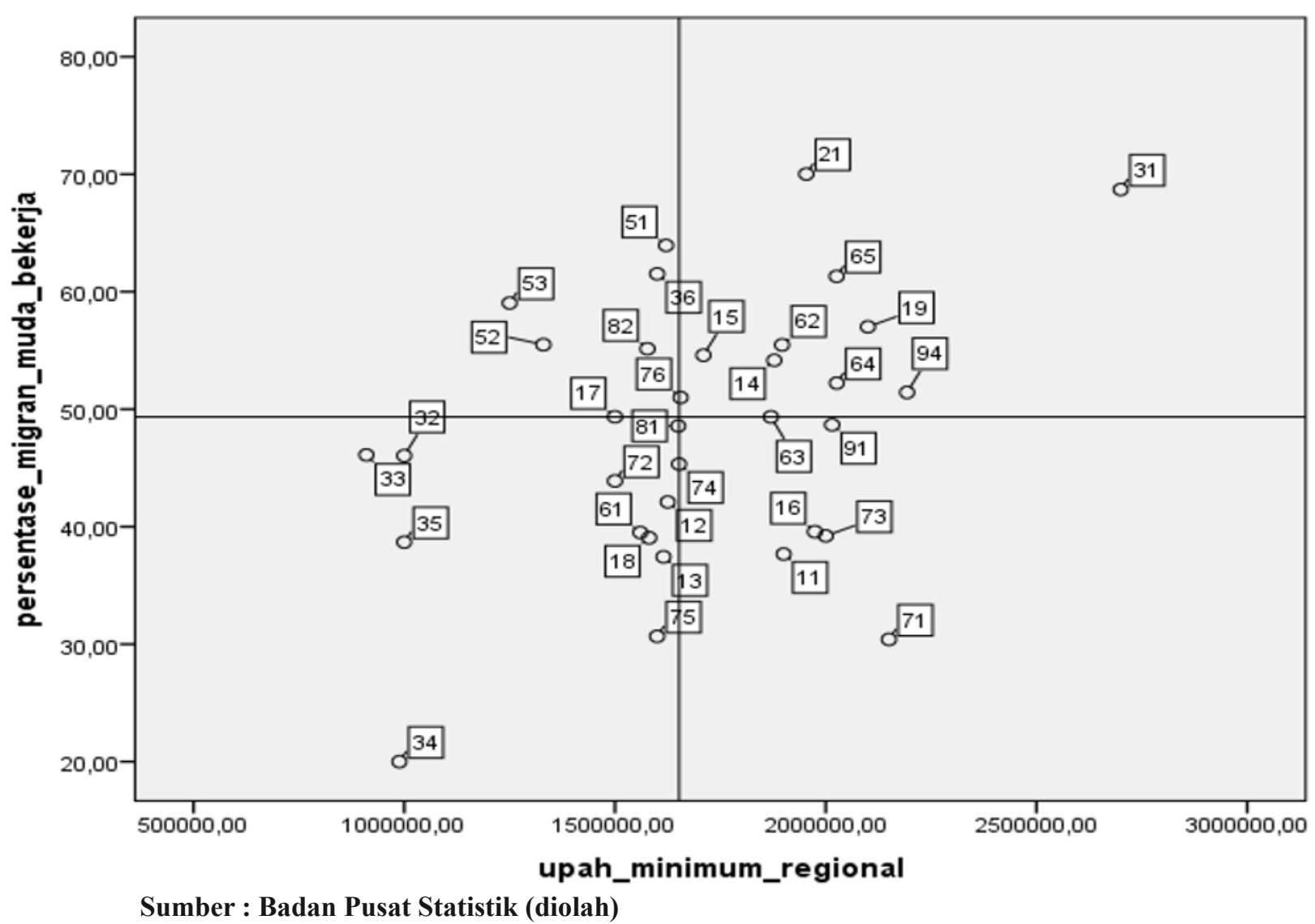

\section{Gambar 9. Scatterplot antara Persentase Migran Muda Bekerja dengan Upah Minimum Regional}

tahun) dan tidak produktif lagi (65 tahun ke bawah rata-rata nasional yang kurang dari $50 \%$ atas) di DKI Jakarta. migran mudanya berstatus bekerja.

Provinsi Nusa Tenggara Barat (52) dan Berdasarkan Gambar 10 yang Nusa TenggaraTimur(53)memilikiupahminimum membagi daerah menjadi empat kuadran, secara regional di bawah rata-rata nasional, mencapai deskriptif ke 34 provinsi di Indonesia tidak (Rp 1.330.000,- dan Rp 1.250.000,-), tetapi lebih menyebar merata ke dalam empat kuadran dari 50\% migran muda di kedua provinsi tersebut tersebut. Dikarenakan banyak provinsi yang berstatus bekerja. Selain itu, keempat provinsi berada pada kuadran I dan kuadran III. Hanya yang berada di pulau Jawa yaitu Jawa Barat (32), terdapat lima provinsi yang berada pada Jawa Tengah (33), DI Yogyakarta (34), dan Jawa kuadran II yaitu provinsi dengan kode 52 (Nusa Timur (35) memiliki upah minimum regional di Tenggara Barat), 53 (Nusa Tenggara Timur, 76 


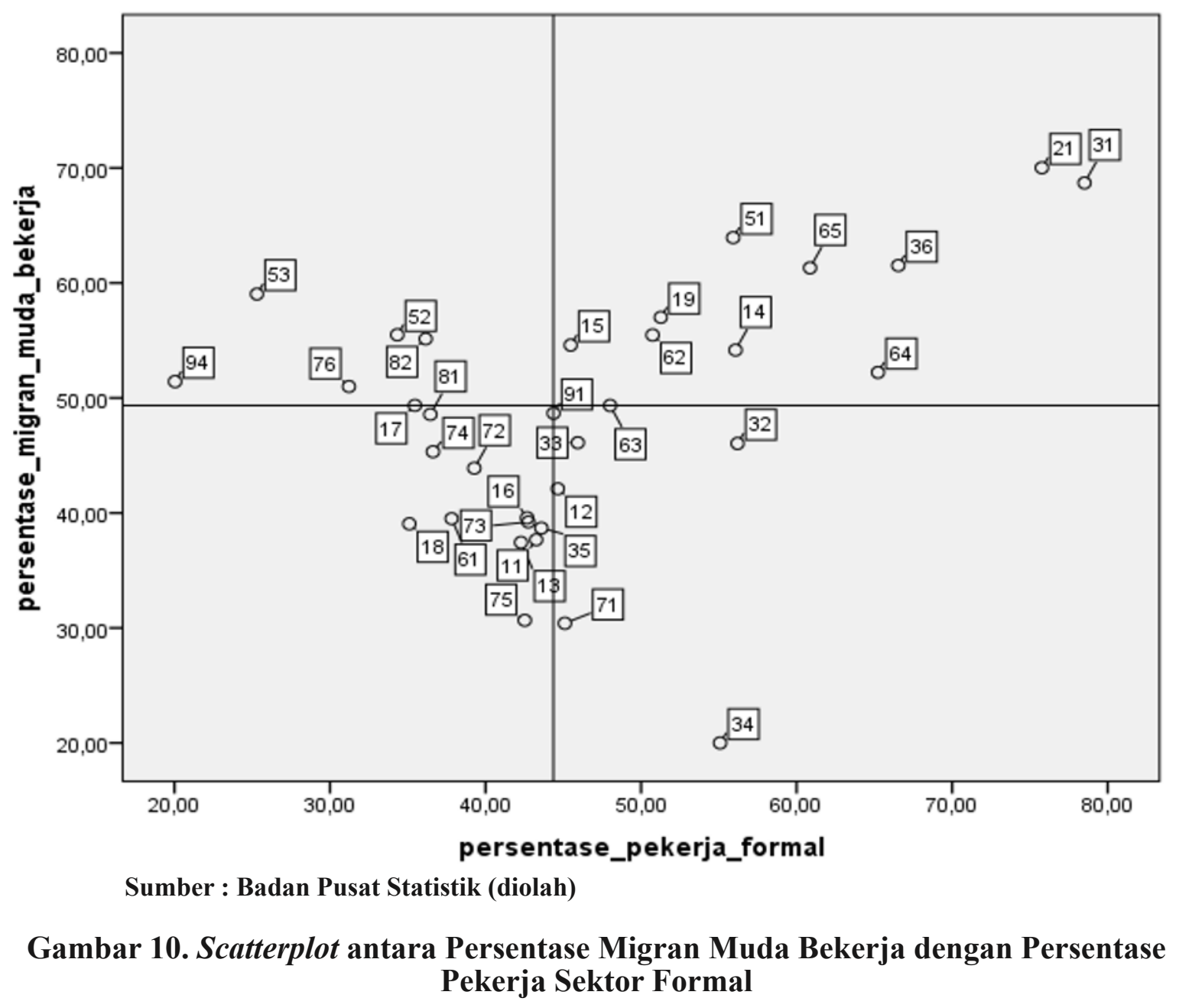

(Sulawesi Barat), 82 (Maluku Utara), dan 94 provinsi tersebut memiliki persentase pekerja (Papua). Artinya, provinsi tersebut memiliki sektor formal yang tinggi namun memiliki persentase migran muda bekerja yang tinggi, persentase migran muda bekerja yang rendah. namun persentase pekerja sektor formal rendah, Hal tersebut bisa terjadi dikarenakan migran terutama provinsi Nusa Tenggara Timur dan muda tertarik untuk pindah menuju provinsi Papua. Hal ini bisa disebabkan karena sebagian tersebut utamanya DI Yogyakarta dan Jawa besar migran muda yang berstatus bekerja di Barat bukan karena pekerjaan, melainkan untuk provinsi tersebut bekerja di sektor informal. Di melanjutkan sekolahnya maupun alasan lain, kuadran IV, terdapat empat provinsi diantaranya selain pekerjaan.

32 (Jawa Barat), 33 (Jawa Tengah), 34 (DI Provinsi dengan kode 21 (Kepulauan Yogyakarta), dan 71 (Sulawesi Utara). Keempat Riau) dan 31 (DKI Jakarta) merupakan 
provinsi paling mencolok di kuadran I. Dimana persentase pekerja sektor formal yang tinggi dan persentase migran muda bekerja yang tinggi pula. Hal tersebut bisa dipahami dikarenakan dominasi Kota Batam sebagai kota industri dan jalur strategis lalu lintas pelayaran, sehingga menciptakan lapangan pekerjaan sektor formal yang cukup tinggi di Provinsi Kepulauan Riau. Hal yang sama juga terjadi di Provinsi DKI Jakarta, sebagai ibu kota negara dan pusat pemerintahan, mayoritas migan muda yang berada di DKI Jakarta bekerja di sektor formal seperti kantor pemerintahan maupun sektor jasa-jasa.

Pengujian Signifikansi Efek Random. Berdasarkan output STATA 13 diperoleh p-value sebesar 0,000 dengan $\alpha=5 \%(p$-value $<\alpha)$ dan nilai Likelihood Ratio test sebesar 506,95 > $\chi_{(0,05,1)}^{2}=3,84$ sehingga diperoleh keputusan untuk menolak $\mathrm{H}_{0}$. Dengan demikian dapat disimpulkan bahwa dengan tingkat signifikansi 5\% terdapat efek random yang signifikan pada keputusan migran muda antarprovinsi untuk bekerja. Hal ini juga mengindikasikan bahwa model multilevel logistik biner lebih baik digunakan untuk memodelkan data yang ada daripada model logistik biner (satu level).
Intraclass Correlation (ICC). Intraclass

Correlation digunakan untuk menghitung besarnya variasi keputusan bekerja migran muda untuk bekerja antarprovinsi dari null model, berdasarkan Lampiran 6. diperoleh nilai ICC sebesar 0,0577541. Angka tersebut menggambarkan bahwa $5,78 \%$ keragaman kecenderungan keputusan bekerja migran muda antarprovinsi di Indonesia disebabkan oleh perbedaan karakteristik antarprovinsi.

Uji Signifikansi Parameter Simultan $\left(\mathrm{Uji} \mathrm{G}^{2}\right)$. Berdasarkan output STATA 13 maka dapat dihitung nilai $\mathrm{G}^{2}$ :

$G^{2}=-2 \ln \left(\frac{\text { Likelihood tanpa variabel penjelas }(\text { null model })}{\text { Likelihood dengan variabel penjelas }(\text { conditional model })}\right)$
$=-2(-6744,2209+4227,4192)=5033,6034$

Nilai Likelihood Ratio test sebesar $\left(>\chi_{(0,05,9)}^{2}=16,92\right)$ sehingga dapat diputuskan tolak $\mathrm{H}_{0}$. Dengan demikian dapat disimpulkan bahwa dengan tingkat signifikansi 5\% terdapat minimal satu variabel independen yang memengaruhi keputusan bekerja migran muda antarprovinsi di Indonesia.

Pengujian Parameter secara Parsial (Uji Wald). Untuk mengetahui variabel penjelas yang memengaruhi keputusan bekerja migran muda antarprovinsi, maka digunakan Uji Wald. $\mathrm{H}_{0}$ ditolak ketika nilai $|\mathrm{Z}|>\alpha$ atau $p$-value $<\alpha$. 
Sehingga dapat diketahui variabel penjelas yang signifikan memengaruhi keputusan bekerja penjelas dengan uji Wald diperoleh hasil bahwa migran muda antarprovinsi di Indonesia. Berikut variabel independen yang signifikan pada $\alpha=$ hasil pengujian variabel independen dalam 0,05 memengaruhi keputusan bekerja migran model multilevel logistik biner menggunakan Uji Wald :
Berdasarkan hasil pengujian variabel muda antarprovinsi di Indonesia adalah jenis kelamin, status dalam rumah tangga, status

Tabel 4.

Hasil estimasi parameter model multilevel logistik biner

\begin{tabular}{|c|c|c|c|c|}
\hline Variabel & Koefisien & $\begin{array}{l}\text { Standard } \\
\text { Error }\end{array}$ & Wald & Odds Ratio \\
\hline (1) & (2) & (3) & (4) & (5) \\
\hline \multicolumn{5}{|c|}{ Faktor Individual } \\
\hline $\begin{array}{c}\text { Jenis Kelamin } \\
\text { Perempuan (ref) } \\
\text { Laki-laki }\end{array}$ & 1,392553 & 0,059521 & $23,40 *$ & 4,025115 \\
\hline $\begin{array}{c}\text { Status Dalam } \\
\text { Rumah Tangga } \\
\text { Bukan KRT (ref) } \\
\text { KRT }\end{array}$ & 0,7571272 & 0,1026423 & $7,38 *$ & 2,132142 \\
\hline $\begin{array}{c}\text { Status Sekolah } \\
\text { Masih Bersekolah } \\
\text { (ref) } \\
\text { Tidak Bersekolah } \\
\text { Lagi }\end{array}$ & 2,705274 & 0,096001 & $28,18 *$ & 14,95842 \\
\hline $\begin{array}{c}\text { Alasan Pindah } \\
\text { Tidak terkait } \\
\text { pekerjaan (ref) } \\
\text { Terkait Pekerjaan }\end{array}$ & 2,01551 & 0,0588013 & $34,28 *$ & 7,504555 \\
\hline $\begin{array}{l}\text { Pendidikan } \\
\text { Terakhir } \\
\text { Dasar (ref) } \\
\text { Menengah } \\
\text { Tinggi }\end{array}$ & $\begin{array}{c}-0,1295626 \\
0,5493828\end{array}$ & $\begin{array}{l}0,0695747 \\
0,1129869\end{array}$ & $\begin{array}{l}-1,86 \\
4,86^{*}\end{array}$ & $\begin{array}{c}0,8784796 \\
1,732184 \\
\end{array}$ \\
\hline \multicolumn{5}{|c|}{ Faktor Kontekstual } \\
\hline $\begin{array}{c}\text { Rasio } \\
\text { Ketergantungan }\end{array}$ & 0,029008 & 0,0104217 & $2,78 *$ & 1,029433 \\
\hline $\begin{array}{c}\text { Upah Minimum } \\
\text { Regional }\end{array}$ & 0,0143357 & 0,011852 & 1,21 & 1,014439 \\
\hline $\begin{array}{l}\text { Persentase Pekerja } \\
\text { Sektor Formal }\end{array}$ & 0,0137126 & 0,0047384 & $2,89 *$ & 1,013807 \\
\hline
\end{tabular}

Keterangan : * = signifikan pada $\alpha=0,05 ;($ ref $)=$ kategori acuan 
sekolah, alasan pindah, pendidikan terakhir, kemungkinan yang lebih tinggi untuk masuk rasio ketergantungan dan persentase pekerja dalam dunia kerja dibandingkan migran muda sektor formal. yang berstatus bukan KRT. Hal ini sejalan

Dengan nilai koefisien variabel jenis dengan penelitian Dyah (2015) secara umum kelamin kategori laki-laki 1,392553, hal itu berarti bahwa migran muda berjenis kelamin laki-laki memiliki kecenderungan sebesar 4,025115 untuk bekerja dibandingkan migran muda berjenis kelamin perempuan dengan asumsi variabel lain dianggap konstan. Dengan kata lain, migran muda laki-laki memiliki kemungkinan yang lebih tinggi untuk bekerja dibandingkan migran muda perempuan. Hal ini sejalan dengan penelitian Lauby dan Stark (2010) bahwa kesempatan pekerjaan yang sedikit membuat migran perempuan lebih cenderung untuk kembali ke rumah atau mengurusi rumah tangga daripada bekerja.

Dengan nilai koefisien variabel status dalam rumah tangga kategori Kepala Rumah Tangga (KRT) 0,7571272, hal itu berarti bahwa migran muda yang berstatus sebagai KRT memiliki kecenderungan sebesar 2,132142 untuk bekerja dibandingkan migran muda yang berstatus bukan KRT dengan asumsi variabel lain dianggap konstan. Dengan kata lain, migran muda yang berstatus sebagai KRT memiliki seorang suami berperan sebagai kepala keluarga yang bertugas mencari nafkah untuk memenuhi kebutuhan sandang, pangan dan papan.

Dengan nilai koefisien variabel status sekolah kategori tidak bersekolah lagi 2,705274, hal itu berarti bahwa migran muda yang berstatus tidak bersekolah lagi memiliki kecenderungan sebesar 14,95842 untuk bekerja dibandingkan migran muda yang berstatus masih bersekolah dengan asumsi variabel lain dianggap konstan. Dengan kata lain, migran muda yang berstatus tidak bersekolah lagi memiliki kemungkinan yang lebih tinggi untuk masuk dalam dunia kerja dibandingkan migran muda yang berstatus masih bersekolah. Hal ini sejalan dengan penelitian McDonald (2010) bahwa banyak pendatang yang bekerja di pekerjaan tingkat rendah seperti pembantu rumah tangga dan pedagang kecil. Mereka putus sekolah pada usia muda karena orangtuanya tidak mampu dan berpendidikan rendah.

Dengan nilai koefisien variabel alasan pindah kategori alasan pekerjaan/mencari 
pekerjaan 2,01551, hal itu berarti bahwa migran muda yang alasan pindahnya karena pekerjaan/ mencari pekerjaan memiliki kecenderungan sebesar 7,504555 untuk bekerja dibandingkan migran muda yang alasan pindahnya selain karena pekerjaan/mencari pekerjaan dengan asumsi variabel lain dianggap konstan. Dengan kata lain, migran muda yang alasan pindahnya karena pekerjaan/mencari pekerjaan memiliki kemungkinan yang lebih tinggi untuk masuk dalam dunia kerja dibandingkan migran muda yang alasan pindahnya selain karena pekerjaan/mencari pekerjaan. Hal ini sejalan dengan penelitian Chotib (2016) mengemukakan bahwa proses migrasi internal dan internasional terjadi sebagai suatu reaksi dari berbagai perbedaan antara daerah asal dan daerah tujuan. Perbedaan ini disebabkan oleh faktor ekonomi, sosial dan lingkungan baik pada level individu maupun komunitas. Beberapa studi migrasi mengindikasikan bahwa migrasi terjadi terutama disebabkan alasan ekonomi, yaitu untuk memperolah pekerjaan dan pendapataan yang lebih tinggi. Maka dapat ditegaskan bahwa migrasi merupakan suatu usaha untuk meningkatkan kualitas hidup.

Hasil pengujian parsial menunjukkan bahwa pendidikan terakhir signifikan memengaruhi keputusan bekerja migran muda antarprovinsi di Indonesia. Namun kategori pendidikan menengah tidak signifikan pada $\alpha=$ 0,05 , dengan nilai koefisien variabel pendidikan terakhir kategori menengah -0,1295626. Sedangkan kategori pendidikan tinggi signifikan pada $\alpha=0,05$ dengan nilai koefisien variabel pendidikan terakhir kategori tinggi 0,5493828, hal itu berarti bahwa migran muda yang pendidikan terakhirnya tinggi memiliki kecenderungan sebesar 1,732184 untuk bekerja dibandingkan migran muda yang pendidikan terakhirnya dasar, dengan asumsi variabel lain dianggap konstan. Dengan kata lain, migran muda yang pendidikan terakhirnya tinggi memiliki kemungkinan yang lebih tinggi untuk masuk dalam dunia kerja dibandingkan migran muda yang pendidikan terakhirnya dasar. Hal ini sejalan dengan penelitian Lamy (2010) permasalahan yang dikhawatirkan terjadi adalah terlalu banyak migran anak-anak tidak akan membuat transisi yang sukses dari sekolah untuk bekerja, dan mereka akan berakhir di posisi terpinggirkan pengangguran atau pelaku kriminal. Anak-anak migran terlihat dalam lingkaran kebijakan sebagai kelompok yang membutuhkan perhatian tambahan jika mereka 
ingin meningkatkan tingkat pendidikan mereka atau harus didorong untuk bergabung dengan pasar tenaga kerja.

Hasil pengujian parsial menunjukkan bahwa rasio ketergantungan signifikan memengaruhi keputusan bekerja migran muda antarprovinsi di Indonesia. Dengan nilai koefisien variabel rasio ketergantungan 0,029008, hal itu berarti bahwa ketika suatu provinsi rasio ketergantungan wilayahnya meningkat satu satuan, maka kecenderungan migran muda untuk bekerja menjadi 2,94\% dengan asumsi variabel lain dianggap konstan. Dengan kata lain, ketika rasio ketergantungan wilayah suatu provinsi semakin tinggi maka semakin tinggi kecenderungan migran muda untuk bekerja. Hal ini sejalan dengan penelitian Zaiceva dan Zimmerman (2014) bahwa rasio ketergantungan sudah mulai meningkat, sementara penduduk usia kerja menurun, proses ini akan berlanjut di masa depan. Selain efek demografi langsung memberikan kontribusi bagi pertumbuhan penduduk dan pergeseran distribusi usia menuju usia yang lebih muda (meskipun migrasi lansia juga menjadi lebih penting), imigrasi juga cenderung meningkatkan kesuburan secara keseluruhan. migran biasanya memiliki kesuburan rata-rata lebih tinggi daripada pribumi, setidaknya pada awal waktu mereka di negara tujuan, tetapi kesuburan menurun pada generasi berikutnya. Negara-negara maju yang mengalami aging problem juga perlu migran untuk alasan lain yaitu meningkatnya pangsa populasi yang lebih tua dapat merangsang permintaan yang lebih tinggi untuk kesehatan dan layanan perawatan secara umum, dan migran mengisi lowongan yang tersedia di negara-negara tersebut.

Hasil pengujian parsial menunjukkan bahwa upah minimum regional tidak signifikan memengaruhi keputusan bekerja migran muda antarprovinsi di Indonesia. Upah minimum regional tidak signifikan dengan nilai koefisien variabel upah minimum regional 0,0143357. Hal ini sejalan dengan penelitian di Cina oleh Fang dan Lin (2013) bahwa pada migran pedesaan upah minimum memiliki efek yang merugikan dan signifikan di wilayah Barat, dan memiliki efek positif (meskipun secara statistik tidak signifikan) di wilayah Timur dalam periode yang sama. Selain itu, penelitian Pamungkas (2015) menjelaskan bahwa upah minimum riil tidak berpengaruh secara signifikan terhadap tenaga kerja remaja. 
Hasil pengujian parsial menunjukkan bahwa persentase pekerja sektor formal wilayah signifikan memengaruhi keputusan bekerja migran muda antarprovinsi di Indonesia. Dengan nilai koefisien variabel persentase pekerja formal wilayah 0,0137126 , hal itu berarti bahwa ketika suatu provinsi persentase pekerja formal wilayah meningkat satu persen maka kecenderungan migran muda untuk bekerja menjadi 1,38\% dengan asumsi variabel lain dianggap konstan. Hasil tersebut sejalan dengan hasil penelitian Brian McCaig dan Nina Pavcnick (2014) yang menyatakan bahwa banyak pekerja di wilayah yang berpenghasilan rendah, memperoleh pekerjaan di sebuah pabrik di sektor formal akan memberikan peningkatan yang signifikan pada kehidupan pekerja tersebut dan penelitian yang dilaksanakan UNFPA tahun 2014 juga menyatakan bahwa pemuda cenderung tidak bekerja di sektor pertanian dan di sektor informal yang masih menonjol, tetapi cenderung untuk mencari pekerjaan di daerah perkotaan dan di berbagai industri jasa dan produksi non-pertanian, di mana terdapat lebih banyak pekerjaan sektor formal yang biasanya memberikan upah dan gaji tetap.

\section{SIMPULAN DAN SARAN}

Kesimpulan yang dapat ditarik adalah sebagai berikut migran muda antarprovinsi di Indonesia didominasi oleh migran muda berjenis kelamin perempuan, berstatus bukan sebagai kepala rumah tangga, berstatus tidak bersekolah lagi, alasan tidak terkait pekerjaan, dan pendidikan terakhirnya tingkat menengah. Faktor individual yang signifikan memengaruhi keputusan untuk bekerja migran muda antarprovinsi di Indonesia diantaranya jenis kelamin, status dalam rumah tangga, status sekolah, alasan pindah, dan tingkat pendidikan. Faktor kontekstual yang signifikan memengaruhi keputusan untuk bekerja migran muda antarprovinsi di Indonesia rasio ketergantungan dan persentase pekerja formal. Hasil odds ratio faktor individual, menunjukkan bahwa kecenderungan migran muda untuk bekerja lebih besar pada migran muda berjenis kelamin laki-laki, berstatus sebagai kepala rumah tangga, berstatus tidak bersekolah lagi, alasan pindahnya terkait pekerjaan, dan pendidikan terakhirnya adalah pendidikan tinggi. Hasil odds ratio faktor kontekstual, menunjukkan bahwa kecenderungan migran muda untuk bekerja semakin tinggi seiring 
dengan meningkatnya rasio ketergantungan dan persentase pekerja formal di tiap provinsi.

Saran yang dapat diberikan adalah diperlukan peningkatan program pengawasan dan perlindungan dari pemerintah terhadap migran muda yang berjenis kelamin laki-laki, berstatus sebagai kepala rumah tangga dan berstatus tidak bersekolah lagi, karena migran muda tersebut memiliki kecenderungan yang lebih tinggi untuk memasuki dunia kerja. Hal ini untuk mencegah eksploitasi pekerja yang seharusnya masih bisa untuk melanjutkan pendidikan ke jenjang yang lebih tinggi. Sehingga bisa meningkatkan pendapatan yang akan mereka dapatkan. Kemudian, kebijakan wajib belajar 12 tahun harus segera diperketat. Supaya migran muda tidak berpikir untuk putus sekolah. Bisa dengan memberikan sekolah gratis bagi mereka yang tidak bisa membayar biaya sekolah. Kemudian peningkatan produktivitas para pekerja melalui jalur pendidikan juga perlu ditingkatkan dalam usaha meningkatkan upah yang diterima untuk mencukupi kebutuhan. Pada penelitian selanjutnya, peneliti bisa menggunakan level dua tingkat kabupaten, dengan cara menjadikan migran risen antarkabupaten sebagai unit analisis.

\section{REFERENSI}

Badan Pusat Statistik. (2015a). Indikator Pasar Tenaga Kerja Indonesia Agustus 2015. Jakarta : BPS.

Chotib. (2016). Faktor-Faktor yang Mempengaruhi Keputusan Bermigrasi Antarpropinsi di Indonesia : Penerapan Model Interaksi Spasial dengan Fungsi Logistik. Jakarta : Lembaga Demografi FE UI

Coulombe, Serge. (2006). Internal Migration, Assymetric Shocks, and Interprovincial Economic Adjusments in Canada. International Regional Science Review 29, 2: 199-223.

Goldstein, Harvey. (1998). Multilevel Statistical Models. New York : Halstead Press.

Fang, Tony, Carl Lin. (2013). Minimum Wages and Employment in China. Bonn : IZA

Hox, J. (2002). Multilevel Analysis. London : Lawrence Earlbaurn Associates.

International Labour Organization. (2015). Angkatan Kerja yang Terampil untuk Pertumbuhan yang Kuat Berkelanjutan dan Seimbang. Geneva : ILO.

Lamy. (2010). Young Migrants Transition from School to Work Obstacles and Opportunities. Netherlands : TRESEGY.

Lauby, Jennifer . Oded Stark. (2010). Individual Migration As a Family Strategy: Young Women in the Philippines. Population Studies 42(3):476-86.

McCaig, Brian. Nina Pavcnik. (2014). Creating Formal Sector Jobs in Low-Income Countries. Growth and Labour Markets in Low Income Countries Programme, LIC Policy Brief No. 4.

McDonald, Peter. et al. (2010). Hasil Pendidikan dan Pekerjaan Pendatang Muda ke Jakarta dan Sekitarnya. ANU-UI : Policy Background No 1.

Pamungkas, Salsa Nopian. (2015). Analisis Pengaruh Upah Minimum Riil terhadap Tenaga Kerja Remaja di Indonesia Periode 2007-2013 [Skripsi]. Jakarta : Sekolah Tinggi Ilmu Statistik.

Purbasari, Dyah., Sri Lestari. (2015). Pembagian Peran dalam Rumah Tangga pada Pasangan Suami Istri Jawa. Jurnal Penelitian Humaniora, Vol. 16, No. 1, 
Februari 2015: 72-85.

United Children's Work Programme. (2012). Understanding children's work and youth employment outcomes in Indonesia. Rome : UCW.

Zaiceva, Anzelika, Klauss F. Zimmermann. (2014). Migration and the Demographic Shift. Bonn : IZA. 